\title{
Characterisation of the geochemical heterogeneity of the Rupel Clay Member in the Netherlands
}

\section{Koenen ${ }^{1, *} \&$ J. Griffioen ${ }^{2,3}$}

1 TNO - Sustainable Geo-energy, Princetonlaan 6, 3584 CB Utrecht, the Netherlands

2 TN0 - Geological Survey of the Netherlands, Princetonlaan 6, 3584 CB Utrecht, the Netherlands

3 Department of Innovation, Environmental and Energy Sciences, Faculty of Geosciences, Utrecht University, P.0. Box 80115, 3508 TA Utrecht, the Netherlands

* Corresponding author. Email: marielle.koenen@tno.nl

Manuscript received: 22 July 2015, accepted: 9 February 2016

\section{Abstract}

Samples from Rupel Clay across the Netherlands were analysed for the assessment of its heterogeneity in geochemistry and mineralogy. X-ray fluorescence (XRF) and bulk and clay fraction X-ray diffraction (XRD) analyses of 152 samples from 17 different cores are presented and statistically interpreted. The results show a wide variation in the quartz, feldspar, clay mineral and carbonate content between the different samples. Factor analysis showed that the main variance between the samples can be explained by the clay mineral and quartz concentration, the carbonate content and pyrite plus organic matter. In the south of the Netherlands, the Rupel Clay is more quartz-rich and coarse grained. In addition, the clay is heterogeneous, varying with location and depth, consistent with observations for Belgium Boom Clay. Towards the north, the Rupel Clay becomes more clay-rich, finer grained and more homogeneous, both laterally and with depth. In addition, the clay has a relatively high carbonate and organic matter content. The pyrite content does not show any trends with location and depth. The differences between north and south are explained by the variations in depositional setting within the southern North Sea Basin.

Keywords: Rupel Clay, geochemical heterogeneity, SPSS

\section{Introduction}

Clay rocks are fine-grained, low-permeable material with a significant amount of clay minerals. These rock types have properties that are favourable for the disposal of radioactive waste because of the large proportion of clay minerals present. These properties include a low permeability, chemical buffering capacity, propensity for plastic deformation and self-sealing of fractures (if the clay is poorly indurated), and a high capacity to retard the migration of radionuclides through sorption onto charged clay surfaces (Boisson, 2005). They are therefore investigated as potential host rock for the disposal of radioactive waste in several European countries, including Belgium, France and Switzerland (Boisson, 2005; Altmann et al., 2012).

The Rupel Clay Member in the Netherlands, approximately equivalent to the Boom Formation in Belgium and the Ratingen and Lintfort Members in Germany, is identified as a potential formation for the future geological disposal of radioactive waste. Within the Dutch research programme, OPERA (Onderzoeksprogramma Eindberging Radioactief Afval), the feasibility and post-closure safety of a repository in this formation is investigated. The geological disposal concept consists of multiple barriers, including an engineered barrier system, the host rock and the overburden. This multiple barrier system needs to contain the radionuclides associated with the radioactive waste and isolate them from the biosphere (Verhoef \& Schröder, 2011). The key functions of a host rock are to provide a stable, geochemically reducing and mechanically stable environment (Mazurek, 2010) and retardation of radionuclides migration through retention after release from the waste containers (Mazurek, 2010; Verhoef \& Schröder, 2011).

In Belgium the geochemistry of Boom Clay has been studied for the purpose of geological disposal of radioactive waste for decades (e.g. Baeyens et al., 1985; Honty, 2008; Honty \& De Craen, 2009). The Boom Clay in the investigated area in Mol is located at a depth of approximately $200-300 \mathrm{~m}$. In the 
Netherlands, the Rupel Clay reaches much greater depths in the south eastern and northern parts of the country (see Vis et al., 2016). Much less is known about the physico-chemical properties of the Rupel Clay in the Netherlands and the effect of the current depth on its suitability for a potential geological disposal facility.

In this paper we characterise the mineralogical and geochemical properties of the Rupel Clay in the Netherlands at a national scale. This is the first time that Rupel Clay has been investigated for mineralogy and geochemistry nationwide. Since detailed mineralogical analyses are not always available, potential geochemical proxies for mineral concentrations have been identified to be used in future studies. We investigated the geographical and depth-related variations by statistical analyses of the dataset. Because of their importance with regard to radionuclide retention, the focus is on the clay minerals. In addition, the presence of pyrite and carbonate minerals are important because of their oxidation and $\mathrm{pH}$ buffering potential, respectively. The results will indicate whether the characteristics of Rupel Clay vary significantly with location and/or depth within the Netherlands, and whether they are comparable to those of the Boom Clay in Belgium.

\section{Sample selection and preparation}

In total 152 sediment samples were selected from 17 different borehole cores from across the Netherlands. Most samples (132) were collected from 15 cores which had been stored in the TNO core house at Zeist for up to several decades. No precautions were taken to protect these cores from drying out and oxidation. Another six samples were taken from core sections provided by COVRA, and 14 samples were taken from a newly drilled core (CAL-GT-02) in Limburg. These two cores were treated with specific precautions to prevent oxidation and desiccation (see also Behrends et al., 2016). The locations of the 17 boreholes are shown in Fig. 1. For the sample selection, as many samples as possible were obtained from locations where the Rupel Clay is at a depth $>400 \mathrm{~m}$ and thicker than $100 \mathrm{~m}$. Because of the limited availability of Rupel Clay core material, several samples were taken which do not comply with these criteria.

In general, the core material from the core house was desiccated, mouldy and/or contained some funghi. Because of preservation regulations and the occasional limited availability of core material, each sample represents a core interval of several centimetres, up to several metres.

\section{Methods}

\section{Geochemical analyses}

The samples were air dried $\left(<40^{\circ} \mathrm{C}\right)$ and pulverised to a 100 mesh $(149 \mu \mathrm{m})$ in a mild-steel pulveriser, according to ASTM standard procedures. They were analysed for major oxides and rare earth and refractory elements, following a lithium metaborate/tetraborate fusion and dilute nitric acid digestion. For precious and base metals, they were analysed following digestion in Aqua Regia. The samples were subsequently analysed by inductively coupled plasma (ICP) emission spectrometry for the major oxides and by ICP mass spectrometry for the total set of rare earth and refractory elements, as well as precious and base metals. Additionally, X-ray fluorescence (XRF) analysis was performed for the major oxides and some rare earth and refractory elements. In both ICP and XRF analysis the loss on ignition (LOI) is calculated, which is the weight difference after ignition at $1000^{\circ} \mathrm{C}$.

Total carbon, organic carbon and total sulphur were measured by Leco combustion elemental analysis. The inorganic carbon content was subsequently calculated by subtracting the organic from the total carbon content.

Thirty samples were selected for X-ray diffraction (XRD) analysis. This selection was based on geographical spreading and depth. Deeper samples were preferred for comparison with the shallower Boom Clay in Belgium. In order to obtain depth profiles, the samples were chosen from 7 out of the 17 cores. Each sample was pulverised in a porcelain mortar and $2.7 \mathrm{~g}$ of material was sampled. An internal standard (0.3 g, Zn0-zincite) was added. The mixture was pulverised in ethanol using Korund elements and subsequently homogenised using a McCrone micronising mill for 5 minutes. The samples were loaded in the XRD sample holders via 'sideloading'. The measurements were performed with a Siemens D5000 in Bragg-Brentano configuration, equipped with a $\mathrm{CuK} \alpha \mathrm{X}$-ray source and a graphite monochromator.

For the mineral identification the program Eva, developed by the Bruker Corporation, and the Crystallography 0pen Database were used. The crystalline phases are quantified via Rietveld methodology. This methodology 'calculates' an XRD pattern based on structure models of the identified minerals the way that they are present in the literature and databases. The pattern is fitted as closely as possible to the measured pattern by refinement of the structure parameters. Because this methodology is not applicable to all clay minerals because of 'stacking disorder', the clay minerals are quantified via the PONKCS (Partial Or No Known Crystal Structures) method (Scarlett \& Madsen, 2006).

The clay fraction was also measured separately by oriented clay slides. For this purpose, $5 \mathrm{~g}$ of sample material was decalcified using a pH-buffering Na-acetate solution. Next, the organic material was removed via oxidation with $\mathrm{H}_{2} \mathrm{O}_{2}$ and Fe-oxides/hydroxides using a Na-hypochlorite solution. Subsequently, the separation of the clay fraction $(<2 \mu \mathrm{m})$ was accomplished by centrifuge. Finally, the clays with exchangeable cations were converted to Ca-containing clays using a saturated $\mathrm{CaCl}_{2}$ solution. The $\mathrm{Cl}$ ions were removed by dialysis. The dried material was mixed with water, applied on a 


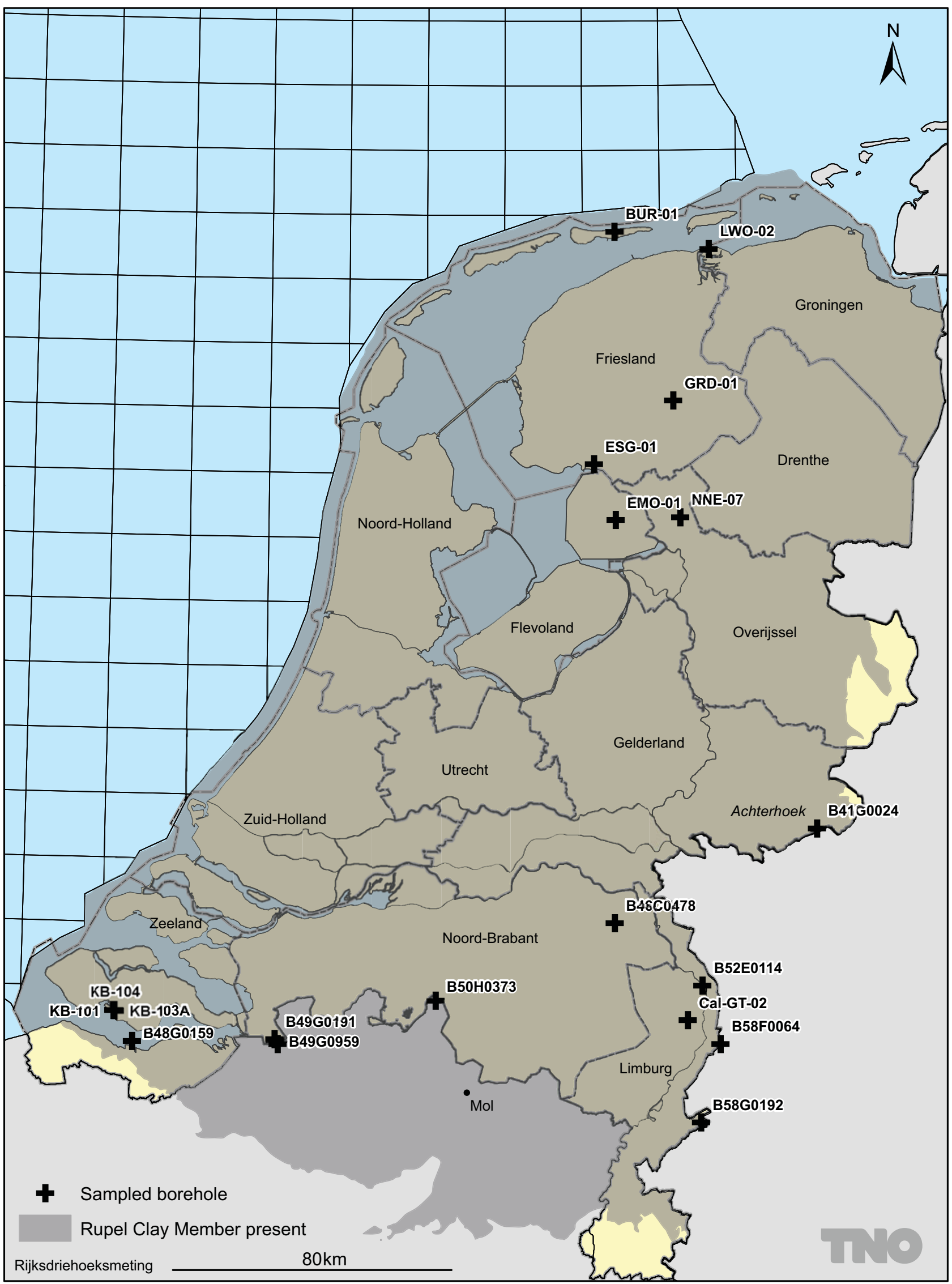

Fig. 1. Map of the Netherlands with the borehole locations. Six samples from the three boreholes KB-101, KB-103 and KB-104 provided by COVRA are shown as one borehole. 
sedimentation plate and measured by XRD, both air dried and saturated in ethylene glycol.

\section{Statistical analyses}

Two statistical analysis methodologies were applied to the geochemical and mineralogical datasets obtained: factor analysis and cluster analysis. These were performed with the statistical software program SPSS Statistics version 20.

Factor analysis is a technique commonly used to identify the main components of variance within a large dataset. It allows the assessment of variables which correlate highly with (a group of) other variables, but correlate badly with others. The variables with high inter-correlations might represent an underlying factor. These factors can be used to evaluate geochemical processes or sediment properties. To select parameters for the factor analysis, correlations between the variables were checked using the correlate procedure in SPSS. Variables which do not correlate with any other variable or which correlate highly with other variables (with $R>0.9$ or $R^{2}>0.81$ ) were eliminated from the dataset. Variables with many analyses below the detection limit were also eliminated. The analysis was performed using principle component extraction by Kaiser normalisation.

A cluster analysis enables the identification of groups with relatively similar geochemical characteristics. The results were used to assess whether geographical or depth-related differences can be observed. The clustering is based on the 'distance' between selected variables of the different samples. This 'distance' is a measure of how far apart the variables are. Clustering can be done in various ways. The most common method is $k$ means clustering. In this approach the number of clusters needs to be assigned a priori. Initial cluster means are randomly chosen and samples are assigned to the clusters to which they are nearest. Then, the cluster means are re-calculated based on the assigned samples. Subsequently, the samples are reassigned to the clusters based on their new cluster means, and the cluster means are calculated again. This process is iterated until the cluster means are stable or the maximum number of iterations is reached. The $k$-means method uses the simple Euclidean measure for calculation of the distance between two samples:

$$
d_{x, y}=\sqrt{\sum_{j=1}^{J}\left(x_{j}-y_{j}\right)^{2}}
$$

Where $x$ and $y$ represent values from two different samples for the same variable, and $j=1 \ldots . . J$ represents all the variables included in the analysis. For the $k$-means cluster analysis a selection of variables was made. Strong outlying values were removed from the dataset to prevent clustering based on single outliers. For each selected variable we evaluated whether its distribution is best described as normal or lognormal. Then, the (log) values of all selected variables were standardised by the following equation:

$$
\begin{aligned}
& \text { standardised value } \\
& \qquad=\text { (original value - mean) / standard deviation }
\end{aligned}
$$

Standardisation is required to correct for variation in variable scales, otherwise the variable with the highest values dominate the clustering procedure. Clustering was performed for a varying number of clusters. The results were compared and the optimal number of clusters was selected.

\section{Results}

The oxides and several minor/trace elements were measured by two different techniques: XRF and ICP. Both techniques should give similar results. However, three samples did not show similar results. These were removed from the dataset.

\section{Rupel Clay geochemistry and mineralogy}

Table 1 shows an overview of the results for a selection of geochemical parameters and mineralogical components. The samples are rich in silica, with $\mathrm{SiO}_{2}$ contents between 45.8 and 88.6 $\mathrm{wt} \%$. They contain lower, but variable, amounts of $\mathrm{Al}_{2} \mathrm{O}_{3}, \mathrm{CaO}$, $\mathrm{Fe}_{2} \mathrm{O}_{3}, \mathrm{~K}_{2} \mathrm{O}$ and minor elements. The organic and inorganic carbon contents are up to 2.5 and $3.5 \mathrm{wt} \%$, respectively. About $35 \%$ of the samples have an inorganic carbon content below 0.1 wt $\%$.

The mineralogy of the 30 samples analysed by XRD is highly variable (Table 1). It consists mainly of quartz (16.3-86.3 wt\%) and clay minerals (8.4-70.2 wt\%, from bulk analysis), with lesser but variable amounts of feldspar, carbonates, pyrite and accessory minerals.

Table 2 shows the correlation matrix between chemical parameters from XRF, and Table 3 between the mineralogy from $\mathrm{XRD}$ and the chemical composition from XRF. As expected, $\mathrm{Al}_{2} \mathrm{O}_{3}$ and $\mathrm{SiO}_{2}$ have a strong negative correlation. They correlate strongly with the (total) clay mineral and quartz content respectively (Fig. 2A and $\mathrm{B}$ ). From the $\mathrm{Al}_{2} \mathrm{O}_{3}$ and $\mathrm{SiO}_{2}$ contents, the total clay and quartz concentrations can be estimated using the following empirical equations:

$$
\begin{aligned}
\text { total clay }(\mathrm{wt} \%) & =3.60 \times \mathrm{Al}_{2} \mathrm{O}_{3}(\mathrm{wt} \%)+1.69(R=0.92) \\
\text { quartz }(\mathrm{wt} \%) & =1.44 \times \mathrm{SiO}_{2}-52.02 \quad(R=0.95)
\end{aligned}
$$

A strong, negative correlation exists between the quartz and total clay mineral content. The 2:1 clay and kaolinite from bulk $\mathrm{XRD}$ analysis both have a positive correlation with $\mathrm{Al}_{2} \mathrm{O}_{3}$. At an $\mathrm{Al}_{2} \mathrm{O}_{3}$ content below $7 \mathrm{wt} \%$, the kaolinite content is constant at a value around $1 \mathrm{wt} \%$. Above $7 \mathrm{wt} \%$, the kaolinite content increases with $\mathrm{Al}_{2} \mathrm{O}_{3}$ (Fig. $2 \mathrm{C}$ ) and can be roughly estimated using the following empirical equation:

$$
\text { kaolinite }(\mathrm{wt} \%)=0.68 \times \mathrm{Al}_{2} \mathrm{O}_{3}(\mathrm{wt} \%)-3.66 \quad(R=0.87)
$$


Table 1. Descriptive statistics of the Rupel Clay in the Netherlands for a selection of geochemical parameters and XRD whole-rock mineralogy.

\begin{tabular}{|c|c|c|c|c|c|}
\hline & $\mathrm{N}$ & Minimum & Maximum & Mean & Standard. deviation \\
\hline $\mathrm{SiO}_{2}$ & 149 & 45.80 & 88.60 & 63.76 & 9.93 \\
\hline $\mathrm{Al}_{2} \mathrm{O}_{3}$ & 149 & 1.92 & 18.83 & 11.68 & 4.09 \\
\hline $\mathrm{Fe}_{2} \mathrm{O}_{3}$ & 149 & 1.62 & 10.45 & 5.06 & 1.33 \\
\hline $\mathrm{CaO}$ & 149 & 0.28 & 14.51 & 2.78 & 2.96 \\
\hline $\mathrm{Mg0}$ & 149 & 0.32 & 2.86 & 1.57 & 0.53 \\
\hline $\mathrm{Na} 20$ & 149 & 0.12 & 2.98 & 0.80 & 0.33 \\
\hline K20 & 149 & 0.85 & 5.58 & 2.72 & 0.66 \\
\hline Mn0 & 149 & 0.01 & 0.11 & 0.02 & 0.02 \\
\hline $\mathrm{TiO}_{2}$ & 149 & 0.12 & 0.96 & 0.68 & 0.17 \\
\hline $\mathrm{P}_{2} \mathrm{O}_{5}$ & 149 & 0.02 & 8.22 & 0.14 & 0.67 \\
\hline Total sulphur & 149 & 0.17 & 2.66 & 0.88 & 0.46 \\
\hline Organic carbon & 149 & 0.07 & 2.46 & 0.85 & 0.48 \\
\hline Inorganic carbon & 149 & 0.00 & 3.45 & 0.55 & 0.67 \\
\hline $\mathrm{Ba}^{*}$ & 149 & 145 & 2126 & 355 & 253 \\
\hline $\mathrm{Rb}^{*}$ & 149 & 27 & 171 & 106 & 30 \\
\hline $\mathrm{Sr}^{*}$ & 149 & 61 & 937 & 215 & 127 \\
\hline $\mathrm{U}^{*}$ & 149 & 1 & 28 & 4 & 2 \\
\hline $\mathrm{Zr}^{*}$ & 149 & 81 & 760 & 289 & 130 \\
\hline Mo* & 149 & 0.1 & 8.4 & 1.4 & 1.7 \\
\hline $\mathrm{Pb}^{*}$ & 149 & 3 & 726 & 24 & 78 \\
\hline $\mathrm{Zn}^{*}$ & 149 & 13 & 444 & 67 & 62 \\
\hline $\mathrm{As}^{*}$ & 149 & 3 & 29 & 9 & 4 \\
\hline Quartz & 30 & 16.35 & 86.34 & 41.50 & 18.19 \\
\hline Plagioclase & 30 & 0.00 & 5.63 & 2.40 & 1.35 \\
\hline K-feldspar & 30 & 2.22 & 11.13 & 6.61 & 2.58 \\
\hline Clinoptilolite/heulandite & 30 & 0.00 & 2.86 & 0.54 & 0.94 \\
\hline Calcite & 30 & 0.00 & 25.93 & 3.75 & 5.88 \\
\hline Aragonite & 30 & 0.00 & 5.14 & 1.01 & 1.29 \\
\hline Ankerite/dolomite & 30 & 0.00 & 1.49 & 0.09 & 0.29 \\
\hline Siderite & 30 & 0.00 & 3.86 & 0.19 & 0.71 \\
\hline Pyrite & 30 & 0.00 & 6.94 & 0.85 & 1.34 \\
\hline Anatase & 30 & 0.00 & 0.94 & 0.42 & 0.29 \\
\hline Sylvite & 30 & 0.00 & 2.19 & 0.19 & 0.59 \\
\hline Halite & 30 & 0.00 & 1.39 & 0.20 & 0.39 \\
\hline Gypsum & 30 & 0.00 & 2.45 & 0.78 & 0.85 \\
\hline Jarosite & 30 & 0.00 & 2.84 & 0.39 & 0.92 \\
\hline Chlorite & 30 & 0.00 & 3.73 & 1.13 & 1.00 \\
\hline 2:1 clay & 30 & 7.24 & 63.13 & 35.88 & 14.95 \\
\hline Kaolinite & 30 & 0.77 & 12.10 & 4.04 & 2.99 \\
\hline Total clay & 30 & 8.45 & 70.16 & 41.05 & 18.11 \\
\hline
\end{tabular}

Values are in wt\% except for values marked $*$, which are in ppm.

The 2:1 clay content can be estimated using the following empirical equation (Fig. 2D):

$$
2: 1 \text { clay }(w t \%)=2.88 \times \mathrm{Al}_{2} \mathrm{O}_{3}(\mathrm{wt} \%)+4.45 \quad(R=0.89)
$$

In addition to $\mathrm{Al}_{2} \mathrm{O}_{3}$, the total clay mineral content also correlates strongly with $\mathrm{MgO}, \mathrm{K}_{2} \mathrm{O}, \mathrm{Fe}_{2} \mathrm{O}_{3}$, organic $\mathrm{C}$ and many rare earth elements (Table 3 ).
The clay mineralogy of the clay fraction is predominantly made up of 2:1 Mg-rich clays. They consist mainly of smectite, interstratified illite-smectite (ISS) and glauconite-smectite, and illite. A small part of the clay fraction is made up of kaolinite and interstratified kaolinite-smectite (KSS). The clay fraction content of the samples based on grain size is uncertain and depends on the grain size analysis technique used (Vis et al., 
Table 2. Correlation matrix between geochemical parameters for the Rupel Clay in the Netherlands ( $N=149$; only values of $|R|>0.50$ are shown).

\begin{tabular}{|c|c|c|c|c|c|c|c|c|c|c|c|c|c|c|c|c|c|c|c|c|c|c|c|c|}
\hline & $\mathrm{SiO}_{2}$ & $\mathrm{Al}_{2} \mathrm{O}_{3}$ & $\mathrm{Fe}_{2} \mathrm{O}_{3}$ & $\mathrm{CaO}$ & MgO & $\mathrm{Na}_{2} \mathrm{O}$ & $\mathrm{K}_{2} \mathrm{O}$ & MnO & $\mathrm{TiO}_{2}$ & $\mathrm{P}_{2} \mathrm{O}_{5}$ & $\mathrm{SO}_{3}$ & $\begin{array}{c}\text { Total } \\
\mathrm{S}\end{array}$ & $\begin{array}{l}\text { Organic } \\
\text { C }\end{array}$ & $\begin{array}{c}\text { Inorganic } \\
\text { C }\end{array}$ & $\mathrm{Ba}$ & Hf & $\mathbf{R b}$ & $\mathrm{Sr}$ & U & $\mathrm{Zr}$ & Mo & $\mathrm{Pb}$ & $\mathrm{Zn}$ & As \\
\hline$\overline{\mathrm{SiO}_{2}}$ & 1.00 & -0.81 & -0.70 & & -0.87 & & -0.57 & -0.57 & -0.69 & & & & -0.57 & & & 0.59 & -0.72 & & & 0.63 & & & & \\
\hline $\mathrm{Al}_{2} \mathrm{O}_{3}$ & & 1.00 & 0.65 & & 0.90 & & 0.72 & & 0.92 & & & & 0.62 & & & -0.62 & 0.94 & & & -0.66 & & & & \\
\hline $\mathrm{Fe}_{2} \mathrm{O}_{3}$ & & & 1.00 & & 0.73 & & & & 0.52 & & & & & & & & 0.60 & & & -0.52 & & & & \\
\hline $\mathrm{CaO}$ & & & & 1.00 & & & & & & & 0.55 & & & 0.94 & & & & 0.89 & & & & & & \\
\hline $\mathrm{Mg} 0$ & & & & & 1.00 & & 0.70 & & 0.82 & & & & 0.51 & & & -0.62 & 0.85 & & & -0.66 & & & & \\
\hline $\mathrm{Na}_{2} \mathrm{O}$ & & & & & & 1.00 & & & & & & & & & & & & & & & & & & \\
\hline $\mathrm{K}_{2} \mathrm{O}$ & & & & & & & 1.00 & & 0.69 & & & & & & 0.62 & & 0.71 & & & & & & & \\
\hline Mn0 & & & & & & & & 1.00 & & & & & & & & & & & & & & & & \\
\hline $\mathrm{TiO}_{2}$ & & & & & & & & & 1.00 & & & & 0.52 & & & & 0.87 & & & & & & & \\
\hline $\mathrm{P}_{2} \mathrm{O}_{5}$ & & & & & & & & & & 1.00 & & & & & & & & & 0.88 & & & & & \\
\hline $\mathrm{S} 03$ & & & & & & & & & & & 1.00 & & & 0.54 & & & & & & & & & & \\
\hline Total S & & & & & & & & & & & & 1.00 & 0.58 & & & & & & & & 0.53 & & & 0.55 \\
\hline Organic C & & & & & & & & & & & & & 1.00 & & & -0.52 & 0.62 & & & -0.54 & & & & \\
\hline Inorganic C & & & & & & & & & & & & & & 1.00 & & & & 0.78 & & & & & & \\
\hline $\mathrm{Ba}$ & & & & & & & & & & & & & & & 1.00 & & & & & & & & & \\
\hline $\mathrm{Hf}$ & & & & & & & & & & & & & & & & 1.00 & -0.55 & & & 0.98 & & & & \\
\hline $\mathrm{Rb}$ & & & & & & & & & & & & & & & & & 1.00 & & & -0.59 & & & & \\
\hline Sr & & & & & & & & & & & & & & & & & & 1.00 & & & & & & \\
\hline $\mathrm{U}$ & & & & & & & & & & & & & & & & & & & 1.00 & & & & & \\
\hline $\mathrm{Zr}$ & & & & & & & & & & & & & & & & & & & & 1.00 & & & & \\
\hline Mo & & & & & & & & & & & & & & & & & & & & & 1.00 & & & \\
\hline $\mathrm{Pb}$ & & & & & & & & & & & & & & & & & & & & & & 1.00 & 0.72 & \\
\hline $\mathrm{Zn}$ & & & & & & & & & & & & & & & & & & & & & & & 1.00 & \\
\hline As & & & & & & & & & & & & & & & & & & & & & & & & 1.00 \\
\hline
\end{tabular}




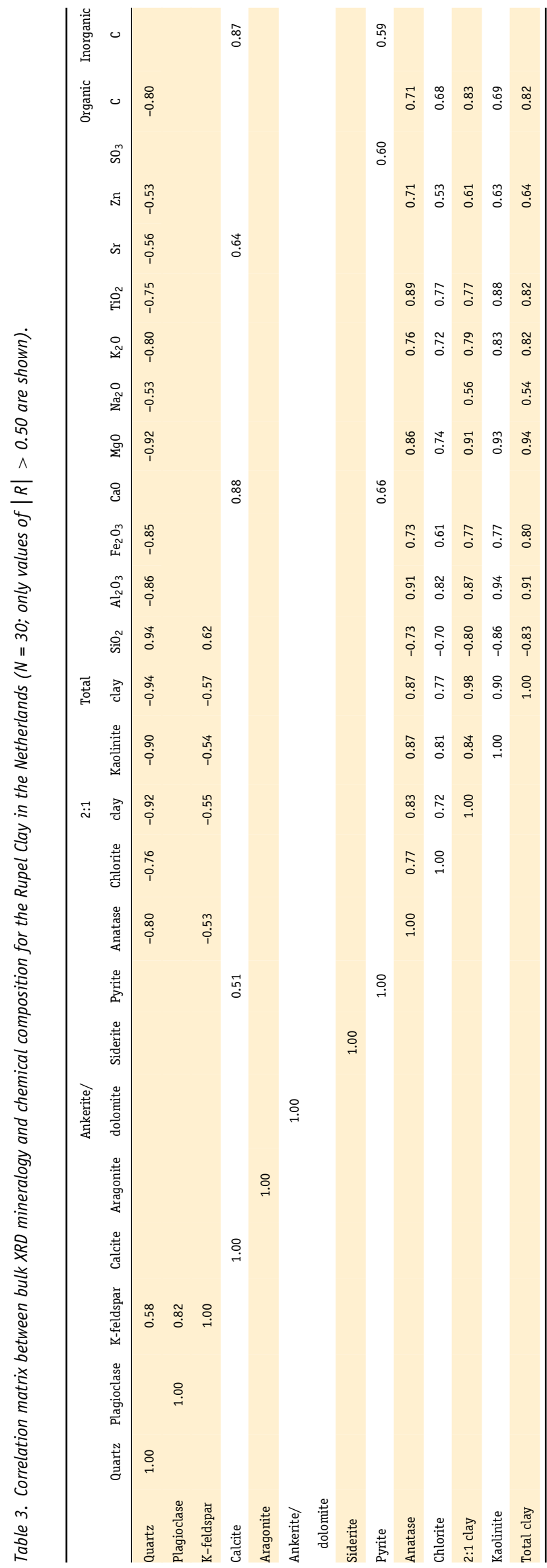

2016). No significant trends were observed between the $\mathrm{Al}_{2} \mathrm{O}_{3}$ content and the clay fraction XRD results (Table 4). Kaolinite (from the clay fraction analysis) shows a moderately positive correlation with illite $(R=0.73)$. Smectite shows a moderately positive correlation with sodium $(R=0.58)$, especially when sodium is corrected for the albite content $(R=0.64)$. In addition, smectite and KSS show a moderately positive correlation with magnesium ( $R=0.49$ and 0.51 , respectively). These correlations are not sufficient to be considered proxies, but they suggest that the smectite present contains sodium and magnesium. This is not unexpected because we expect saline pore water with high $\mathrm{Na}$ and $\mathrm{Mg}$ concentrations in Rupel Clay (Griffioen et al., 2016a; Behrends et al., 2016).

The carbonate content varies strongly between the samples and consists of calcite (up to $25.9 \mathrm{wt} \%$ ), aragonite (up to 5.1 $w t \%)$ and occasionally small amounts of ankerite/dolomite and siderite (Table 1). The amount of calcite and total $\mathrm{CaCO}_{3}$ (calcite plus aragonite) can be estimated from the $\mathrm{CaO}$ content by the following empirical equations (Fig. 2E):

$$
\begin{array}{cc}
\text { calcite }(\mathrm{wt} \%)=1.70 \times \mathrm{CaO}(\mathrm{wt} \%)-1.14 & (R=0.97) \\
\text { total } \mathrm{CaCO}_{3}(\mathrm{wt} \%)=1.83 \times \mathrm{CaO}(\mathrm{wt} \%)-0.51 & (R=0.97)
\end{array}
$$

Strong correlations were found between $\mathrm{CaO}$ and inorganic carbon $(R=0.94)$ as well as $\operatorname{Sr}(R=0.89)$ (Table 2$)$. The correlation between calcite and $\mathrm{Sr}$ is not as strong $(R=0.64)$, and is absent between aragonite and $\mathrm{Sr}$, suggesting the presence of an additional calcium phase with $\mathrm{Sr}$ as an impurity. Strontium can be present as an impurity in gypsum (Ichikuni \& Musha, 1978; Denison et al., 1998), but these do not correlate. It can also replace calcium in heulandite, which is a tecto-silicate of the zeolite group. Currently it is unclear what causes the strong correlation between $\mathrm{CaO}$ and $\mathrm{Sr}$. The $\mathrm{MgO}$ and $\mathrm{Fe}_{2} \mathrm{O}_{3}$ concentrations do not correlate with inorganic carbon, consistent with low concentrations of $\mathrm{Mg}$ - and Fe-containing carbonates, the presence of other Fe-containing minerals and a correlation of $\mathrm{MgO}$ with clay content. Geochemical proxies for siderite, ankerite and dolomite were not found in the dataset.

The pyrite content is generally between zero and $1 \mathrm{wt} \%$. Higher values of 1.8 and $3.5 \mathrm{wt} \%$ were measured for two out of six of the new samples of the CAL-GT-02 borehole. One extreme value of $6.9 \mathrm{wt} \%$ was measured in a sample from core $\mathrm{B} 50 \mathrm{H} 0373$ in the south, probably because of a local heterogeneity. The pyrite concentration has a moderate, positive correlation with total S from Leco combustion if the sample with extreme pyrite content is excluded, and can be roughly estimated by the following equation:

$$
\text { pyrite }(\mathrm{wt} \%)=1.12 \times \text { total } \mathrm{S}(\mathrm{wt} \%)-0.34 \quad(R=0.77)
$$

The organic carbon content and the trace elements molybdenum and arsenic correlate moderately positive with total S (Table 2). Both gypsum and jarosite are present as sulphur-containing minerals in several samples, yet they are absent in the six 

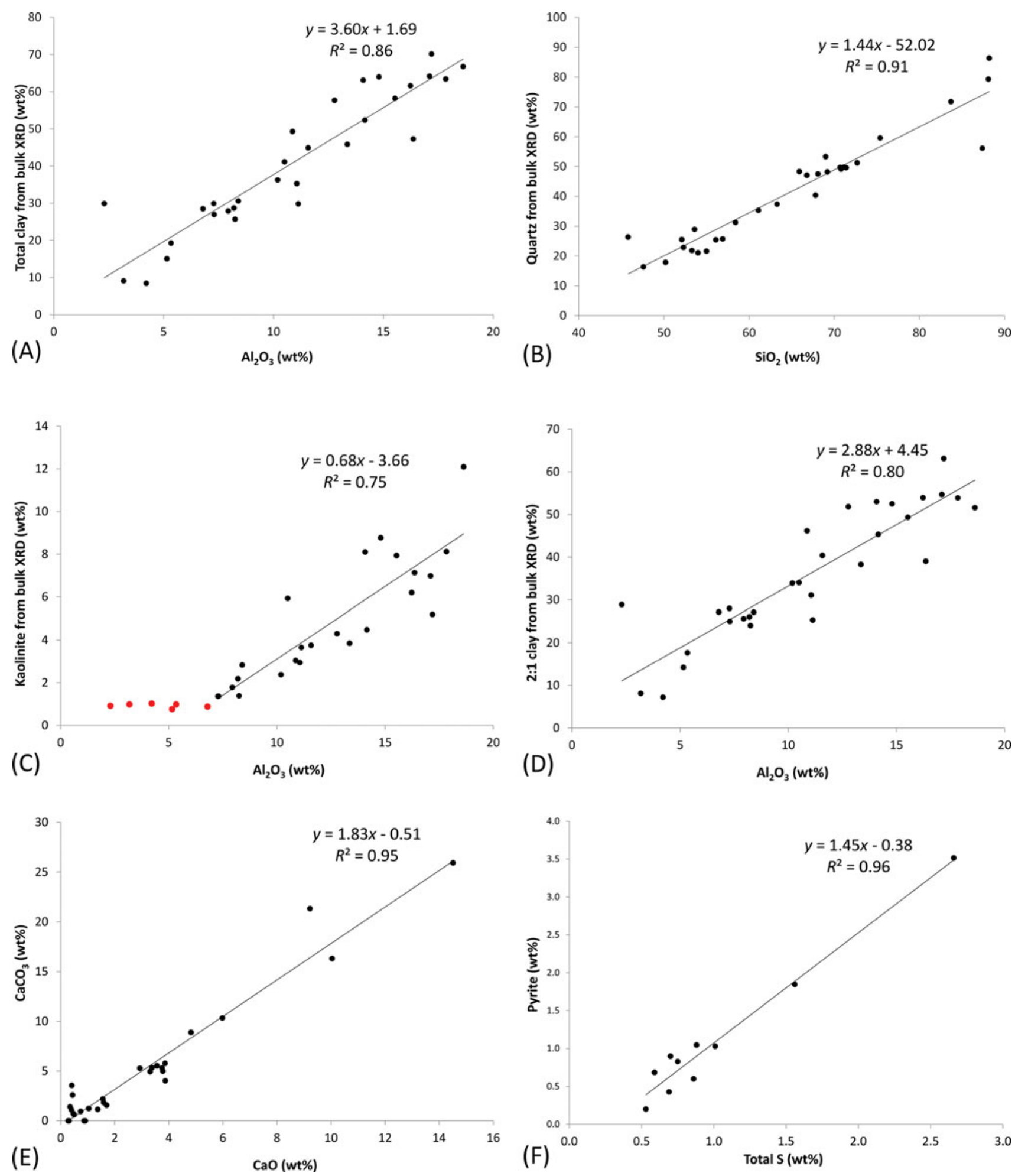

Fig. 2. A. The $\mathrm{Al}_{2} \mathrm{O}_{3}$ concentration from XRF versus total clay mineral content from bulk XRD. $B$. The SiO $\mathrm{O}_{2}$ concentration from XRF versus quartz content from bulk XRD; $C$. The $\mathrm{Al}_{2} \mathrm{O}_{3}$ concentration from XRF versus kaolinite content from bulk XRD; red dots show stable kaolinite content up to $\mathrm{Al}_{2} \mathrm{O}_{3}$ of 7 wt\%, black dots show a linear increase and corresponding regression line; $D$. The $\mathrm{Al}_{2} \mathrm{O}_{3}$ concentration from XRF versus total 2:1 clay mineral content from bulk XRD; E. The $\mathrm{CaO}$ concentration from XRF versus $\mathrm{CaCO}_{3}$ content from bulk XRD. F. Total $S$ from Leco combustion versus pyrite content from bulk XRD for a part of the dataset (see text). 
samples from the new borehole, the one sample from the COVRA core which was treated with specific precautions to prevent oxidation and desiccation (Behrends et al., 2016), and also the three samples of core LWO-2 in the north. These samples are the only ones that contain clinoptilolite/heulandite (zeolite minerals), which could be an artifact from drilling since zeolites are sometimes used as additives in drilling muds. The small amounts of gypsum present in most samples can be assumed to have formed during storage under atmospheric conditions, as a result of calcium reaction with sulphuric acid from pyrite oxidation. The calcium could have originated from the zeolites, although it is unclear why the zeolites would break down. Any strontium present in the zeolites could have been incorporated in the gypsum. Generally it is assumed that pyrite oxidation is accompanied by $\mathrm{CaCO}_{3}$ dissolution to buffer the $\mathrm{pH}$, and subsequent gypsum precipitation (Deutsch, 1997). Also the occasional presence of minor jarosite can be assumed to be an artefact of pyrite oxidation (Larsson et al., 1990). As a consequence, the pyrite content in situ is probably higher than the values measured for the dried samples from the core house. Based on the nine samples in which pyrite is the only sulphur-containing mineral, the following equation for pyrite was obtained (Fig. 2F):

$$
\text { pyrite }(w t \%)=1.45 \times \text { total } \mathrm{S}(\mathrm{wt} \%)-0.38 \quad(R=0.98)
$$

Hence, the estimation of the pyrite from the total dataset would be an underestimation. Applying the latter equation to the total dataset, using the total $S$ values from Leco combustion, the pyrite content is between zero and $3.5 \mathrm{wt} \%$ with an average of $0.9 \mathrm{wt} \%$.

\section{Factor analysis}

The factor analysis resulted in four major (principle) components, or factors, which explain $63.6 \%$ of the variance between the samples. These factors are:

1. The clay mineral content, represented by mainly aluminium and magnesium. Because of the strong negative correlation between the clay mineral and quartz content, this component also represents the (negative) quartz content by a negative loading for silica. This factor is essentially a result of depositional sorting.

2. The $\mathrm{CaCO}_{3}$ content, represented by calcium and inorganic carbon. The aragonite content is assumed to have a detrital origin (e.g. shells), while the calcite, which represents the main part, can be either detrital or authigenic.

3. The organic matter (and pyrite) content, represented by total sulphur, organic carbon and molybdenum. The organic matter content is a depositional effect and results in low redox potential, which is required for pyrite formation. The association of organic matter and pyrite reflects reducing conditions. 
Table 5. Average geochemical cluster compositions from the cluster analysis.

\begin{tabular}{|c|c|c|c|c|c|c|}
\hline \multicolumn{7}{|c|}{ Cluster } \\
\hline & 1 & 2 & 3 & 4 & 5 & 6 \\
\hline $\mathrm{SiO}_{2}$ & 70.9 & 87.7 & 86.8 & 53.0 & 69.6 & 57.8 \\
\hline $\mathrm{Al}_{2} \mathrm{O}_{3}$ & 10.4 & 2.7 & 4.5 & 14.1 & 7.5 & 16.0 \\
\hline $\mathrm{Fe}_{2} \mathrm{O}_{3}$ & 4.3 & 3.0 & 2.4 & 6.1 & 4.4 & 5.8 \\
\hline $\mathrm{CaO}$ & 0.9 & 1.1 & 0.3 & 5.0 & 4.5 & 0.9 \\
\hline $\mathrm{MgO}$ & 1.4 & 0.4 & 0.5 & 2.0 & 1.1 & 1.9 \\
\hline $\mathrm{Na}_{2} \mathrm{O}$ & 0.8 & 0.1 & 0.4 & 1.0 & 0.7 & 0.7 \\
\hline $\mathrm{K}_{2} \mathrm{O}$ & 2.7 & 1.0 & 1.8 & 2.8 & 2.3 & 3.1 \\
\hline Mn0 & 0.02 & 0.01 & 0.01 & 0.04 & 0.02 & 0.02 \\
\hline $\mathrm{TiO}_{2}$ & 0.7 & 0.2 & 0.3 & 0.7 & 0.5 & 0.8 \\
\hline $\mathrm{P}_{2} \mathrm{O}_{5}$ & 0.06 & 0.07 & 0.04 & 0.12 & 0.07 & 0.08 \\
\hline $\mathrm{Cr}_{2} \mathrm{O}_{3}$ & 0.02 & 0.01 & 0.01 & 0.02 & 0.02 & 0.02 \\
\hline $\mathrm{SO}_{3}$ & 0.3 & 0.1 & 0.0 & 0.6 & 0.7 & 0.4 \\
\hline $\mathrm{V}_{2} \mathrm{O}_{5}$ & 0.02 & 0.01 & 0.01 & 0.02 & 0.01 & 0.03 \\
\hline Organic C & 0.6 & 0.4 & 0.2 & 1.0 & 0.6 & 1.3 \\
\hline Inorganic C & 0.1 & 0.2 & 0.1 & 1.1 & 0.9 & 0.1 \\
\hline $\mathrm{Ba}$ & 336 & 178 & 301 & 272 & 328 & 312 \\
\hline $\mathrm{Rb}$ & 99 & 36 & 57 & 118 & 80 & 141 \\
\hline $\mathrm{Sr}$ & 139 & 89 & 81 & 320 & 270 & 148 \\
\hline $\mathrm{U}$ & 2.9 & 1.2 & 1.8 & 3.7 & 2.9 & 4.2 \\
\hline $\mathrm{Zr}$ & 352 & 184 & 364 & 181 & 418 & 216 \\
\hline Mo & 0.9 & 1.1 & 0.7 & 1.7 & 1.7 & 1.3 \\
\hline $\mathrm{Pb}$ & 10.5 & 4.5 & 11.9 & 19.2 & 7.8 & 18.1 \\
\hline $\mathrm{Zn}$ & 53 & 18 & 19 & 122 & 35 & 68 \\
\hline As & 6.8 & 9.1 & 4.5 & 8.0 & 10.7 & 11.6 \\
\hline Number of samples & 35 & 3 & 3 & 36 & 36 & 36 \\
\hline
\end{tabular}

4. The zircon content represented by zircon and hafnium. Zircon is positively associated with quartz as a result of depositional sorting, but the variance is not as strong as the clay versus quartz content.

\section{Rupel Clay geochemical heterogeneity}

The cluster analysis was performed using a selection of variables consisting of all major oxides, organic and inorganic $\mathrm{C}$ and several trace elements. Rubidium is included as element representative for all trace elements which correlate strongly with clay minerals. These include $\mathrm{Co}, \mathrm{Cs}, \mathrm{Ga}, \mathrm{Nb}, \mathrm{Ta}, \mathrm{Th}, \mathrm{V}, \mathrm{Y}$, La, Ce, Pr, Nd, Sm, Eu, Gd, Tb, Dy, Ho, Er, Tm, Yb, Lu and Ni. The following variables were treated as lognormal instead of normal distributed: $\mathrm{CaO}, \mathrm{MnO}, \mathrm{SO}_{3}$, inorganic $\mathrm{C}$ and all trace elements.

The cluster analysis for six clusters resulted in the most optimal distribution of samples. A higher number of clusters resulted in either no interesting sample distributions or the formation of single-sample clusters (outliers). In the six-cluster case, complete cores or core intervals are represented in the clusters.

The average cluster compositions for the six-cluster case are shown in Table 5. Clusters 1 and 5 both represent intermediate quartz and clay contents, with cluster 1 poor and cluster 5 rich in calcium carbonate. Clusters 4 and 6 are both poor in quartz and rich in clay minerals, with cluster 4 rich and cluster 6 poor in calcium carbonate. These results show that the clustering is based on the first two components of the factor analysis, which represent clay mineral, quartz and calcium carbonate content. The other two components, organic matter and zircon, are positively correlated with clay minerals and quartz, respectively, yet the average concentrations of their representing variables are not as dominant as those of the main components. The small clusters 2 and 3 are very similar and represent silicarich and hence quartz-rich samples. Both are low in aluminium (and hence clay minerals) and calcium (and hence calcium carbonate). Some consistent differences in the minor components caused the separation into two clusters, but these differences are not crucial. Hence, the two clusters can be treated as one. 
The distribution of the samples over the six clusters shows geographical as well as depth-related patterns. Almost all of the samples of the cores in the northern Netherlands are represented by cluster 4. Hence, the Rupel Clay in the North is relatively homogeneous with the lowest quartz and high clay mineral, carbonate, organic matter and pyrite contents.

The cores in the south of the Netherlands have more variable compositions. The upper and lower part of these cores are generally rich in quartz and relatively poor in clay. The middle part of the cores is mostly richer in clay, but quartz-rich intervals occur. The carbonate content is low in the southwest. In the southeast the carbonate content varies within the quartz-rich upper and lower parts of the cores, but is generally low in the more clay-rich middle parts. The most southern cores in the East are particularly quartz-rich and low in clay mineral content.

\section{Discussion}

Newly obtained data on geochemistry and mineralogy are presented. The newly presented data can be compared with results on Belgian Boom Clay and with other Dutch (marine or freshwater) sediments.

Bulk and clay fraction XRD analyses provided basic mineral information and showed a wide range in quartz, feldspar, clay mineral and carbonate content within Dutch Rupel Clay. The overall mineralogy is similar to Belgian Boom Clay (Honty, 2008; Honty \& De Craen, 2009). The XRF and XRD data interpretation, as well as the factor analysis, showed that the variation in sample geochemistry is mainly defined by the quartz and clay mineral content, the carbonate fraction, and the organic material and pyrite content. The latter two are identified as a combined factor in the factor analysis. Remarkably, the organic matter shows a moderate, positive correlation with the clay content, while the pyrite does not. In a comparable study on Belgian Boom Clay for the clay products industry, the same factors and correlations were observed (Decleer et al., 1983), yet Decleer et al. (1983) observed a clear correlation between organic matter, pyrite and the clay mineral content. According to the authors, this correlation is mainly sedimentological and reflects reducing conditions. Possibly, either the iron and/or sulfate availability was more variable with time in the Netherlands, which could be an explanation for the lack in clear correlation between clay and pyrite content.

A sequential factor analysis was performed on a geochemical dataset of unconsolidated Late Quaternary fluvial deposits from the Rhine-Meuse delta plain in the Netherlands (Hakstege et al., 1993; Van Helvoort et al., 2005). Like the Rupel Clay and the Belgian Boom Clay, the clay mineral content is the most important factor explaining the variance between the samples, with fine sand and carbonates having a negative loading (Hakstege et al., 1993). For floodplain deposits of the Rhine-Meuse delta plain, the carbonate, and pyrite plus organic matter, repre- sent the second and third factors, respectively (Hakstege et al., 1993), similar to Rupel Clay. For the combined results of six different sedimentary facies of the Rhine-Meuse delta plain, these two factors are reversed (Van Helvoort et al., 2005), implying that the effect of changes in redox conditions have a higher impact than the variation in carbonate content. In addition, the carbonate factor for the Rhine-Meuse deposits is combined with the albitic feldspar content, a correlation which was not found for Rupel Clay. The carbonate in the Rhine-Meuse deposits is identified as detrital fragments that were co-deposited with albite in crevasse-levee deposits due to similar weight (Van Helvoort et al., 2005). The feldspar in the Rupel Clay is correlated with quartz, and has negative loadings on the clay factor, implying the dominance of depositional sorting. In addition, the sodium content is not as strongly correlated with albite as in the Rhine-Meuse deposits because of the correlation of sodium with the clay mineral content.

The combination of XRD and XRF performed in this study allowed the definition of a number of geochemical proxies for the estimation of the quartz, clay mineral (total clay, kaolinite and 2:1 clays) and carbonate (calcite and total $\mathrm{CaCO}_{3}$ ) fraction based on XRF data. These geochemical proxies can be used in future studies in which mineralogical analysis is not performed. Unfortunately, such proxies were not found for the clay minerals of the clay fraction XRD analysis.

The clay mineralogy is a crucial aspect in the safety assessment of the disposal of radioactive waste in facilities in claytype host rocks due to their high specific surface area and cation exchange capacities (CEC) (Altmann et al., 2012), yet detailed assessment of the clay mineralogy is complex. Bulk and clay fraction analysis provide basic information. Compared to more recent Rhine and Meuse fluvial clays, the kaolinite content of Rupel Clay is high, while vermiculite is absent. According to Breeuwsma (1985), the absence of vermiculite in marine clays could be because of the presence of salt (Griffioen et al., 2016b). Vermiculite has a lower swelling potential than smectite, but a higher CEC. Kaolinite, on the other hand, does not swell and has a low CEC. Illite, which is a major clay mineral in both fluvial and marine clays, also does not have swelling potential, and its CEC is intermediate (Appelo \& Postma, 2005). The combination of bulk and clay fraction XRD with XRF allowed an improved assessment of the types and composition of clay minerals present, compared to XRD analyses only. The $\mathrm{Al}_{2} \mathrm{O}_{3}$ from XRD and 2:1 clay from bulk XRD strongly correlate with magnesium, iron and sodium (corrected for albite), showing that these elements are (mainly) present in the clay mineral fraction. Magnesium and sodium are especially related to smectite. These relations suggest that the type of smectite present is Na-montmorillonite, a clay mineral which has the highest swelling potential of all clay minerals and an intermediate CEC.

Pyrite, which is the most common iron sulphide (Roberts et al., 1969), is another important component for the postclosure safety of radioactive waste disposal because of its 
oxidation potential. 0xidising conditions might occur in the host rock near field during and after construction of the repository (De Craen et al., 2008, 2011), by heating and radiation as a result of the radioactive waste (Zhang et al., 2008) or eventually under long-term geological conditions when strong erosion of the overburden happens. Dissolution of pyrite results in a $\mathrm{pH}$ decrease that will affect the geochemical equilibrium and initiates mineral-fluid reactions. If present, $\mathrm{pH}$ buffering will occur by calcite dissolution, and subsequent precipitation of gypsum and/or jarosite (De Craen et al., 2008). The formation of gypsum and jarosite in the samples analysed in this study is interpreted to be the result of storage under atmospheric conditions, but these oxidation reactions may also occur in situ.

In addition, because of the tendency of pyrite to include toxic elements as impurities in its crystal structure, such as molybdenum and arsenic, oxidation of pyrite might release these toxic elements into the biosphere (Huerta-Diaz \& Morse, 1992; Schoonen, 2004). Unfortunately, the concentrations of pyrite by XRD from the cores stored under atmospheric conditions are probably not representative of subsurface conditions because of the oxidation of pyrite to gypsum and/or jarosite. The pyrite concentrations of the new samples from boreholes CAL-GT-02 and COVRA, and the samples from borehole LW0-02, which do not contain any pyrite oxidation products, show a potentially strong proxy of total $S$ for the pyrite content, but a greater number of samples, and hence a higher $N$ value, would be required.

The clustering analysis showed a lateral variation of Rupel Clay geochemistry and mineralogy. In the north of the Netherlands, the Rupel Clay has relatively high clay mineral, carbonate and organic matter contents. The variation with depth is relatively low, showing the homogeneous character of the clay in the north. In the south, the clay is much more quartz-rich and is heterogeneous laterally as well as with depth. The variation in pyrite content is independent of both location and depth. The difference in clay mineral content and heterogeneity between north and south is consistent with grain size distributions, which show consistently smaller grain sizes in the north and limited variability in distributions with depth (Vis et al., 2016). This is explained by the depositional environment, which was characterised by the Cenozoic Southern North Sea Basin, the Rupelian sea, with an approximately east-west trending coastline located in Belgium (Vis et al., 2016). At the southern margin of the basin, the deposition of the Rupel Clay was under the influence of sea level variation, resulting in the presence of quartz-rich intervals, and an increase in quartz content and grain size towards the bottom (towards the Tongeren and Dongen Formations in the east and southwest) and top (towards the sandy Steensel Member or Breda Formation) (Vis et al., 2016). The Boom Clay in Belgium shows comparable geochemical characteristics to the Rupel Clay in the south of the Netherlands. Grain sizes are relatively large, reflecting the high quartz content and the silty nature of the Member. Towards the top and bottom, the Rupel Clay is more sandy, with a more clay-rich central part. Sandy intervals within the clay-rich zone are also observed (Honty, 2008).

Towards the north-northwest, the depth of the basin increased, consistent with the decreasing grain size and increasing clay fraction, and hence clay mineral, content in the $\mathrm{Ru}-$ pel Clay. In this area, the Rupel Clay is overlain by the claydominated Veldhoven Member or Breda Formation (Vis et al., 2016).

\section{Conclusions}

The Oligocene Rupel Clay Member in the Netherlands is heterogeneous at the national scale and consists mainly of quartz, clay minerals and carbonates in varying amounts. Minor components consist of pyrite, anatase and organic matter. 0xidation artefacts in older samples were identified. Geochemical proxies were defined for the mineralogy based on comparison of the datasets of XRD and XRF analyses. Such proxies can be used in future studies if XRD analyses are not available.

XRD bulk and clay fraction analyses show that the clay fraction is composed of a suite of different clays, including kaolinite, smectite, illite and interstratified clays. The smectite seems to be (partially) Na-montmorillonite, but more detailed analyses are required to verify this. Vermiculite was not identified.

In the south of the Netherlands, the Rupel Clay is generally more quartz-rich, coarse grained and heterogeneous with location and depth. The lateral variations and heterogeneous nature are consistent with the observations for the Belgium Boom Clay. Towards the north, the Member becomes more clayrich, finer grained and more homogeneous, both laterally and with depth. In addition, the clay has a relatively high carbonate and organic matter content. The pyrite content does not show any trends with location and depth. The differences between north and south are explained by the variations in depositional setting within the southern North Sea Basin.

\section{Acknowledgements}

The research leading to these results has received funding from the Dutch research programme on geological disposal OPERA. OPERA is financed by the Dutch Ministry of Economic Affairs and the public limited liability company ElektriciteitsProduktiemaatschappij Zuid-Nederland (EPZ) and coordinated by COVRA.

\section{References}

Altmann, S., Tournassat, C., Goutelard, F., Parneix, J., Gimmi, T. \& Maes, N., 2012. Diffusion-driven transport in clayrock formations. Applied Geochemistry $27: 463-478$. 
Appelo, C.A.J. \& Postma, D., 2005. Geochemistry, groundwater and pollution, 2nd edition. CRC Press (Boca Raton, FL): 672 pp.

Baeyens, B., Maes, A., Cremers, A. \& Henrion, P.N., 1985. In situ physicochemical characterization of Boom Clay. Radioactive Waste Management and the Nuclear Fuel Cycle 6: 391-408.

Behrends, T., van der Veen, I., Hoving, A. \& Griffioen, J., 2016. Pore water - Boom Clay interactions. Netherlands Journal of Geosciences. DOI: 10.1017/njg.2016.23

Boisson, J.-Y., 2005. Clay Club Catalogue of characteristics of Argillaceous Rocks. NEA No. 4436. OECD (Paris): 72 pp.

Breeuwsma, A., 1985. Kleimineralogische en chemische karakteristieken van zeeklei, rivierklei en beekklei. rapport no. 1869. Stichting voor bodemkartering (Wageningen): $34 \mathrm{pp}$

De Craen, M., Van Geet, M., Honty, M., Weetjens, E. \& Sillen, X., 2008. Extent of oxidation in Boom Clay as a result of excavation and ventilation of the HADES URF: Experimental and modelling assessments. Physics and Chemistry of the Earth 33: 350-362.

De Craen, M., Honty, M., Van Geet, M., Weetjens, E., Sillen, X., Wang, L., Jacques, D. \& Martens, E., 2011. Overview of the oxidation around galleries in Boom Clay (mol, Belgium) - Status 2008. External Report of the Belgian Nuclear Research Centre, Mol, Belgium - SCK.CEN-ER-189: 92p.

Decleer, J., Viaene, W. \& Vandenberghe, N., 1983. Relationships between chemical, physical and mineralogical characteristics of the Rupelian Boom Clay, Belgium. Clay Minerals 18: 1-10.

Denison, R.E., Kirkland, D.W. \& Evans, R., 1998. Using strontium isotopes to determine the age and origin of gypsum and anhydrite beds. Journal of Geology 106 (1): 1-18.

Deutsch, W.J., 1997. Groundwater Geochemistry: fundamentals and applications to contamination. Lewis Publishers and CRC Press (Boca Raton, FL): 232 pp.

Griffioen, J., Klaver, G. \& Westerhoff, W., 2016a. The mineralogy of suspended matter, fresh and Cenozoic sediments in the fluvio-deltaic Rhine-MeuseScheldt-Ems area, the Netherlands: An overview and review. Netherlands Journal of Geoscience 95 (1): 23-107.

Griffioen, J., Stuurman, R. \& Verweij, H., 2016b. The composition of groundwater in Paleogene and older formations in the Netherlands. A synthesis. Netherlands Journal of Geosciences. DOI: 10.1017/njg.2016.19

Hakstege, A.L., Kroonenberg, S.B. \& Van Wijck, H., 1993. Geochemistry of Holocene clays of the Rhine and Meuse rivers in the central-eastern Netherlands. Geologie en Mijnbouw 71: 301-315.
Honty, M., 2008. SMARAGD - The study of mineral alterations of clay barriers used for radwaste storage and its geological disposal. SCK-CEN, report no. SCK.CEN-ER-58, 08/Mho/P-12: 100 pp.

Honty, M. \& De Craen, M., 2009. Mineralogy of the Boom Clay in the Essen-1 borehole. SCK-CEN, report no. SCK.CEN-ER-87, 09/Mho/P-35: $40 \mathrm{pp}$.

Huerta-Diaz, M.A. \& Morse, J.W., 1992. Pyritization of trace metals in anoxic marine sediments. Geochimica et Cosmochimica Acta 56: 26812702.

Ichikuna, M. \& Musha, S., 1978. Partition of strontium between gypsum and solution. Chemical Geology 21 (3-4): 359-363.

Larsson, L., Olsson, G., Holst, O. \& Karlsson, H.T., 1990. Pyrite oxidation by thermophilic archaebacterial. Applied Environmental Microbiology 56 (3): 697-701.

Mazurek, M., 2010. Far-field process analysis and radionuclide transport modelling in geological repository systems. In: Geological repository systems for safe disposal of spent nuclear fuels and radioactive waste. Woodhead Publishing Limited (Cambridge) and CRC Press (Boca Raton, FL): 222257.

Roberts, W.M.B., Walker, A.L. \& Buchanan, A.S., 1969. The chemistry of pyrite formation in aqueous solution and its relation to depositional environment. Mineralium Deposita 4: 18-29.

Scarlett, N.V.Y. \& Madsen, I.C., 2006. Quantification of phases with partial on no known crystal structures. Powder Diffraction 21: 278-284.

Schoonen, M.A.A., 2004. Mechanisms of sedimentary pyrite formation. Geological Society of America Special Papers 379: 117-134.

Van Helvoort, P-J., Filzmoser, P. \& Van Gaans, P.F.M., 2005. Sequential Factor Analysis as a new approach to multivariate analysis of heterogeneous geochemical datasets: An application to a bulk chemical characterization of fluvial deposits (Rhine-Meuse delta, The Netherlands). Applied Geochemistry 20: 2233-2251.

Verhoef, E. \& Schröder, T., 2011. Research plan. COVRA, report no. OPERA-PGCOV004: $52 \mathrm{pp}$.

Vis, G.-J., Verweij, J.M. \& Koenen, M., 2016. The Rupel Clay Member in the Netherlands: towards a better understanding of its depositional environment. Netherlands Journal of Geosciences. DOI: 10.1017/njg.2016.25

Zhang, G., Samper, J. \& Montenegro, L., 2008. Coupled thermo-hydro-biogeochemical reactive transport model of CERBERUS heating and radiation experiment in Boom Clay. Applied Geochemistry 23: 932-949. 